\section{Role of smallholder tea growers in carbon sink management}

\author{
Rinku Moni Kalita, Ashesh Kumar Das* and \\ Arun Jyoti Nath \\ Department of Ecology and Environmental Science, \\ Assam University, Silchar 788 011, India
}

One-fourth of the total tea production in India comes from smallholder tea estates, thus signifying the importance of this land use in biomass carbon management. As small-scale tea plantation management provides livelihood security to the growers, they prefer to manage such plantation over a long period of time and therefore maintaining a permanent sink of carbon. In the present study from Barak Valley part of North East India, such smallholder plantations were assessed for carbon stock in tea bushes, shade trees and soil compartment. Allometric equation for tea plants developed from this region was used for estimation of biomass carbon stock in tea bushes, while species-specific volume equations were used for shade trees. Carbon stock of biomass, litter layer and soil compartment in smallholder tea plantations were estimated as $30.50 \mathrm{Mg}, \quad 5.54 \mathrm{Mg}$ and $122.17 \pm$ $9.82 \mathrm{Mg} \mathrm{C} \mathrm{ha}^{-1}$ up to $1 \mathrm{~m}$ depth respectively. Shade tree compartment contributed a dominant proportion $(56.37 \%)$ of biomass and carbon stock compared to tea bushes $(25.46 \%)$ and litter layer (18.17\%). Collectively soil compartment holds maximum proportion $(80 \%)$ of carbon stock followed by shade tree $(11 \%)$, tea bush $(5 \%)$ and litter $(4 \%)$ compartments in the system. Comparatively carbon stock in smallholder tea estate is lower than many of the tropical and subtropical forestry and agroforestry systems. Nonetheless, the former sustains the livelihood of million of farmers across the tropical world and simultaneously maintains a permanent sink of carbon. Further studies are required to better understand the tea agroforestry arrangement to promote sink capability of smallholder tea estates.

Keywords: Biomass carbon stock, climate change mitigation, phytosociology, smallholder tea growers.

ACCURATE quantification of the world's carbon (C) budget has become an increasing priority for better understanding of the global carbon cycle, development of climate policies and projecting future climate change ${ }^{1}$. The concentration of carbon dioxide $\left(\mathrm{CO}_{2}\right)$ in the atmosphere had reached $404.21 \mathrm{ppm}$ by May 2016. The atmospheric $\mathrm{CO}_{2}$ growth rate was estimated at $3.9 \pm 0.2 \mathrm{GtC}$ in 2014 (ref. 2). The management of terrestrial ecosystems is known to play an important role in mitigation actions against human-induced climate change ${ }^{3}$ and par-

\footnotetext{
*For correspondence. (e-mail: asheshkd@gmail.com)
}

ticularly in the land use, land-use change and forestry sector (LULUCF). The post-Kyoto Protocol and the Doha amendment to the United Nations Framework Convention on Climate Change (UNFCCC) era drew substantial attention in bracing $\mathrm{CO}_{2}$ level in the atmosphere encouraging varied land-use systems as $\mathrm{C}$ sinks. The woody perennial-based land-use systems have relatively high capacity for capturing and storing atmospheric $\mathrm{CO}_{2}$ in vegetation, soils and biomass products ${ }^{4}$.

Tea [Camellia sinensis (L.) O. Kuntze] is an intensively managed perennial cash crop grown under a canopy of trees which provide partial shade. It is an intensively managed perennial monoculture crop cultivated on largeand small-scale plantations. India has acquired an exalted status on the global tea map as the second largest tea producer in the world, with production of over $1.209 \mathrm{Tg}$ annually covering about $5700 \mathrm{~km}^{2}$ area under plantation ${ }^{5}$. India is ranked fourth in terms of tea export, which reached $0.2 \mathrm{Tg}$ during 2014-15 and was valued at US\$ 619.96 million. Most of the tea plantations have been established in forests and play a predominant role in the maintenance of terrestrial ecology by providing extensive land cover and preventing soil erosion. North East India with $81 \%$ of tea cultivation area accounts for $80 \%$ of total tea production in the country. Assam is the largest tea-producing state in India. This state alone produces approximately $52 \%$ of the total tea ${ }^{6}$. The Barak Valley retains $7.6 \%$ share of total tea production in $11 \%$ of the total area under cultivation in Assam. Tea gardens are the most important feature of economy of the Barak Valley, where tea occupies $5.75 \%\left(396.41 \mathrm{~km}^{2}\right)$ of the total geographical area ${ }^{6}$.

At a global scale, majority of tea is produced in largerscale plantations; smallholders play a crucial role in the tea sector worldwide. Smallholder production is important in developing countries like India, Kenya, Sri Lanka and Vietnam as the leading exchange earner and providing livelihood to a large fraction of the population. Smallholder tea plantations can be considered as alternative and sustainable agricultural practice that takes into account environmental, social and economic impacts collectively. The smallholders producing $25 \%$ of the global tea are among the largest and successful in the world with about 0.4 million stakeholders ${ }^{7,8}$. Sri Lanka accounts for $75 \%$, and Kenya $66 \%$ of tea production by smallholders. In case of the world's leading producers, viz. China and Vietnam, tea production is basically dominated by smallholders, while in Indonesia smallholders account for $23 \%$ of the production ${ }^{7-9}$.

In India, a small grower is one who cultivates 10.12 ha or less area, and does not possess his own tea processing factory. An estimated 160,000 smallholders account for over $26 \%$ of tea production of $0.97 \mathrm{Tg}$ in the country. It has been estimated that about $9760 \mathrm{~km}^{2}$ area is cultivated by 123,000 growers in small-scale tea cultivation in India. Smallholder growth in India has been significant in 
the last decade as the share of output from smallholders increased from $11 \%$ to $26 \%$ during that period ${ }^{7}$. Traditionally, smallholder concept in India is largely oriented to the lower end of the domestic market and considered as low-cost-low-quality production. At present in Barak Valley, there are 1200 registered small tea growers ${ }^{5}$, with a large fraction of growers in Cachar district, Assam. Tea agroforestry has the ability to link economic gains with environmental benefits with the potential to act as a considerable reservoir of biomass carbon providing climate change mitigation options.

Studies assessing structural composition and carbon stock potential of tea plantations in India, Sri Lanka, China and Kenya are available ${ }^{10-13}$ and have also been carried out in Barak Valley ${ }^{14}$. In this context smallholder tea plantations are yet unexplored, although these stocks could be an important carbon sink which would fill the gap compared to large-scale plantations, native forest vegetation and changes in agricultural land use. With this background, the present study analyses standing carbon stock in smallholder tea estates and its implication for climate change mitigation.

The study was conducted in tea-growing areas of Cachar district (lat. $24^{\circ} 22^{\prime}-25^{\circ} 8^{\prime} \mathrm{N}$; long. 92 $24^{\prime}-$ $\left.93^{\circ} 15^{\prime} \mathrm{E}\right)$ of Barak Valley, Assam, NE India. The topography of the terrain is highly undulating characterized by hills, hillocks, falls within the range of the Himalayan foothills and the Barak river basin, and is flanked by the southern belt of the Borail range. The site experiences subtropical, warm and humid climate with an average rainfall of $2159 \mathrm{~mm}$, temperature between $10^{\circ} \mathrm{C}$ and $35.6^{\circ} \mathrm{C}$, and relative humidity of $75.6 \%$.

For sampling the vegetation in smallholder tea plantations, reconnaissance survey of the area was carried out ${ }^{15}$. Information about plantation history and ages was obtained from the tea growers. In ten different plantations of similar age (plantation year 2000-2001), sample plots (quadrat) of 0.1 ha $(31.6 \mathrm{~m} \times 31.6 \mathrm{~m})$ were placed randomly in the sites for sampling shade trees. Table 1 provides a description of the sample sites. For sampling tea bushes, one quadrat of $5 \mathrm{~m} \times 5 \mathrm{~m}$ size was centrally placed within the 0.1 ha plot $^{15}$. All trees exceeding $10 \mathrm{~cm}$ circumference over bark at breast height $(1.37 \mathrm{~m})$ were uniquely identified and tagged, and were measured for girth using a metal tape. The girth of all the tea bushes within the $5 \mathrm{~m} \times 5 \mathrm{~m}$ sample plots was measured at $5 \mathrm{~cm}$ height from the ground. Wood density for different shade tree species was estimated by extracting wood cores using increment borer (Haglof, Sweden) at $1.3 \mathrm{~m}$ height from the ground ${ }^{16}$. In case of species for which wood density was not estimated in the present study, data were collected from the Forest Research Institute, Dehradun ${ }^{17}$ and Global Wood Density Database ${ }^{18}$.

Above-ground biomass (AGB) in shade trees was estimated using species-specific volume equation and regional volume equations developed by Forest Survey of
India (FSI), Dehradun ${ }^{19}$, multiplying wood density (WD) and biomass expansion factor (BEF). In case of all other species for which specific equations were not available, area-specific generalized volume equation developed by FSI was used. Biomass estimation of trees of $\leq 10 \mathrm{~cm}$ DBH (diameter at breast height) was done by relating the basal area and tree biomass in the plots ${ }^{20}$. Belowground biomass (BGB) was calculated by multiplying the AGB by a factor of 0.26 as the root-to-shoot ratio ${ }^{21}$. In the present study, BEF value of 1.58 was used. The IPCC default value of 0.47 has been used for the carbon fraction of shade tree biomass ${ }^{22}$.

Allometric equations were used to estimate tea biomass $^{23}$. Standard methodology was adopted for carbon estimation in biomass. Allometric equations for tea biomass estimation using single predictor variable diameter are as follows

$$
\begin{aligned}
& \mathrm{AGB}=0.047 \times(\text { diameter })^{1.878}, \\
& \mathrm{BGB}=0.014 \times(\text { diameter })^{1.870} .
\end{aligned}
$$

Biomass carbon stock in the plantation site was assessed summing carbon stock values of different compartments. Litter samples were collected from randomly laid quadrats of $50 \mathrm{~cm} \times 50 \mathrm{~cm}$ size in different plantations ${ }^{24}$. Fresh weight of the litter was measured on site and subsamples were collected for biomass and $\mathrm{C}$ determination. Removing the top organic litter, soil samples from three replicates were collected at depths of 0-30, 30-50 and 50-100 cm (ref. 25). Soil colour was determined using Munsell soil colour chart. Soil texture was determined using Bouyoucos soil hydrometer method (type ASTM no. $152 \mathrm{H})^{26}$. Bulk density (BD) of soil was determined by Corer technique ${ }^{27}$. Organic carbon content of the soil samples was examined using the modified Walkely and Black method proposed by Chan et al. ${ }^{28}$. Total soil C was determined by the dry combustion process using a CHNS/O ElementarVario EL III analyzer (configured in CHN-mode). Carbon stock in the system was assessed summing carbon stock values of different compartments.

Data collected in the study were entered and arranged for analysis using Microsoft Excel 2010 version. Kolmogorov-Smirnov and Shapiro-Wilk tests were performed to check normality of the data. While data analysis and statistical tests were performed using MS Excel 2010 and SPSS 20 respectively, $t$-test was performed to analyse significant difference of parameter estimates among different sites. ANOVA was performed to find significance of mean difference of data following normal distribution.

Eighteen different species of shade trees were encountered across the different study sites. Indigofera tysmanii is the dominant shade tree species registering an occurrence of $31.4 \%$ followed by Albizia chinensis (13.7\%), A. odoratissima (12.6\%) and Senna siamea (9.7\%). In different plantations, shade tree density varied from 100 to 


\section{RESEARCH COMMUNICATIONS}

Table 1. Description of the study sites in smallholder tea plantations in Barak Valley, Northeast India

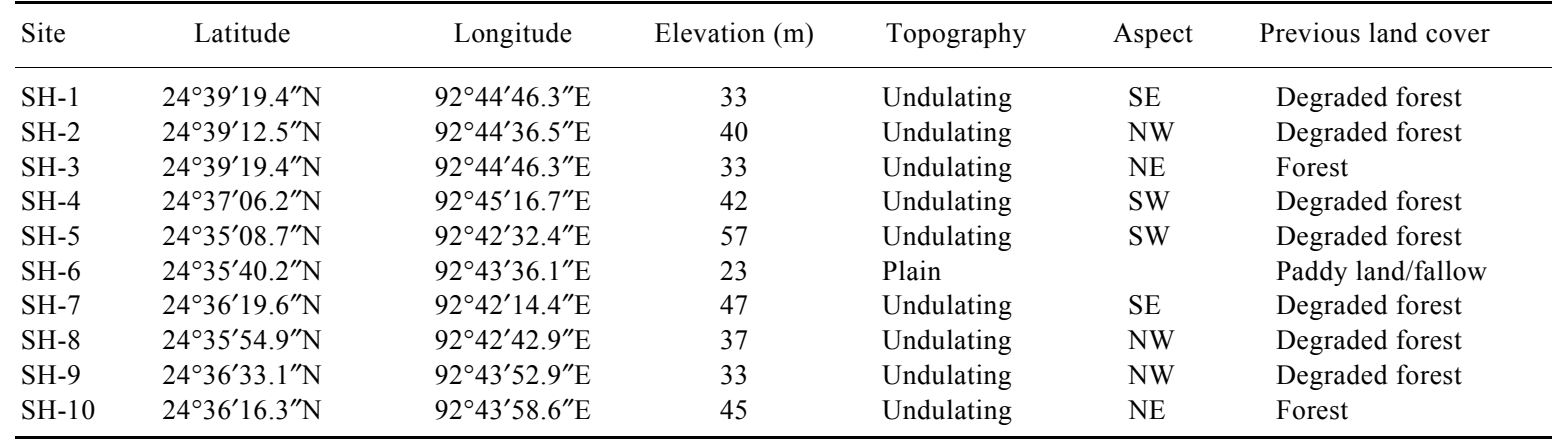

Table 2. Descriptive statistics for density, basal area and carbon stock in different compartments under smallholder tea plantations

\begin{tabular}{|c|c|c|c|c|c|c|c|}
\hline Parameters & Compartment & Mean & Minimum & Maximum & SD & $\mathrm{SE}$ & CV (\%) \\
\hline \multirow{3}{*}{ Density (stem ha ${ }^{-1}$ ) } & Shade tree & 175 & 100 & 390 & 83.82 & 26.50 & 47.89 \\
\hline & Tea bush & 9640 & 7600 & 13600 & 1862.90 & 589.10 & 19.32 \\
\hline & Total & 9815 & 7700 & 13750 & 1849.39 & 584.83 & 18.84 \\
\hline \multirow[t]{3}{*}{ Basal area $\left(\mathrm{m}^{2} \mathrm{ha}^{-1}\right)$} & Shade tree & 4.69 & 3.03 & 9.59 & 1.92 & 0.61 & 40.94 \\
\hline & Tea bush & 26.05 & 20.62 & 31.91 & 3.96 & 1.25 & 15.18 \\
\hline & Total & 30.73 & 24.46 & 37.86 & 4.79 & 1.52 & 15.59 \\
\hline \multirow[t]{4}{*}{ Carbon stock $\left(\mathrm{Mg} \mathrm{ha}^{-1}\right)$} & Shade tree & 17.19 & 8.98 & 41.33 & 9.32 & 2.95 & 54.23 \\
\hline & Tea bush & 7.77 & 6.15 & 9.49 & 1.17 & 0.37 & 15.01 \\
\hline & Litter & 5.54 & 4.33 & 7.23 & 0.96 & 0.30 & 17.30 \\
\hline & Total biomass & 30.50 & 21.99 & 56.74 & 9.96 & 3.15 & 32.64 \\
\hline \multirow{4}{*}{$\begin{array}{l}\text { Soil organic carbon (SOC) } \\
\text { stock }\end{array}$} & $0-30 \mathrm{~cm}$ & 54.47 & 24.47 & 80.66 & 15.36 & 4.86 & 28.20 \\
\hline & $30-50 \mathrm{~cm}$ & 22.45 & 13.08 & 32.48 & 6.30 & 1.99 & 28.06 \\
\hline & $50-100 \mathrm{~cm}$ & 45.24 & 29.98 & 70.42 & 12.62 & 3.99 & 27.90 \\
\hline & $0-100 \mathrm{~cm}$ & 122.17 & 70.09 & 183.55 & 31.06 & 9.82 & 25.43 \\
\hline Carbon stock $\left(\mathrm{Mg} \mathrm{ha}^{-1}\right)$ & Total & 152.67 & 107.69 & 210.63 & 31.55 & 9.98 & 20.66 \\
\hline
\end{tabular}

SD, Standard deviation; SE, Standard error; CV, Coefficient of variation.

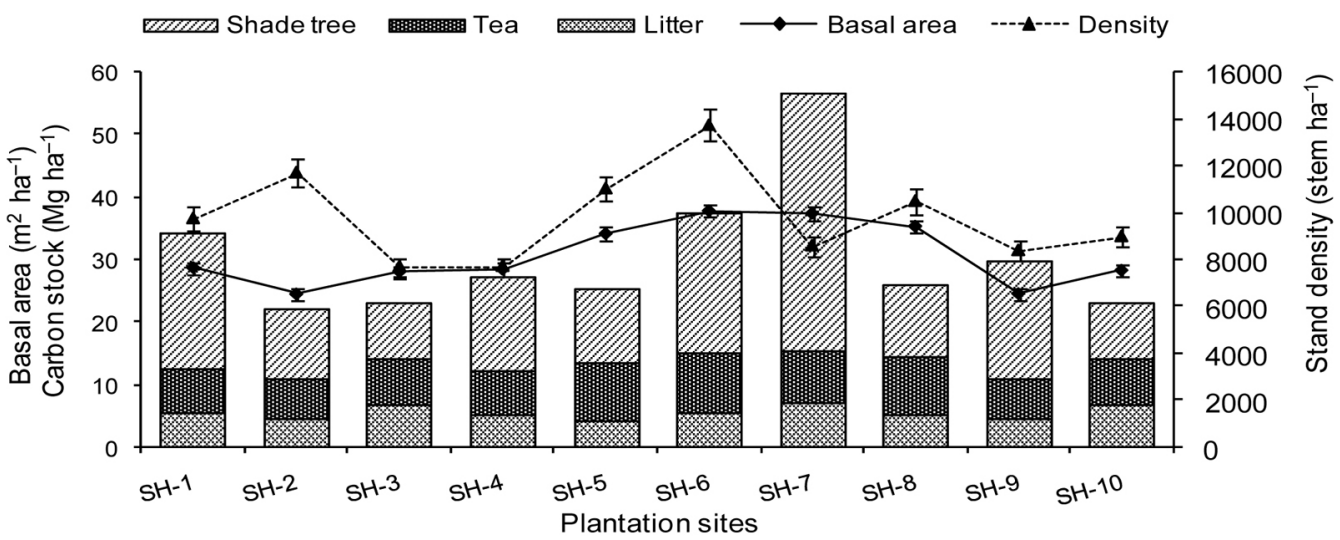

Figure 1. Density, basal area and biomass carbon allocation in different compartments under smallholder tea plantations.

390 stems ha ${ }^{-1}$. Basal area ranged from 3.03 to $9.59 \mathrm{~m}^{2} \mathrm{ha}^{-1}$. Tea bush density varied from 7600 to 13,600 stems ha $^{-1}$. Accordingly, tea bush basal cover exhibited values between 20.62 and $31.91 \mathrm{~m}^{2} \mathrm{ha}^{-1}$ (Table 2). Shade tree density in different plantations varied significantly $(P<0.010)$. Tea bush density and basal area exhibited significant mean difference at 0.01 level in different plan- tations ( $t$-test; $P<0.01)$. Stand basal cover among the plantations was estimated to be $30.73 \pm 4.79 \mathrm{~m}^{2} \mathrm{ha}^{-1}$, depicting a range of 24.46 (SH-2) to $37.86 \mathrm{~m}^{2} \mathrm{ha}^{-1}$ (SH-6) with significant difference ( $t$-test; $P<0.01$ ) (Figure 1).

Tea bush emerged as the dominant component in the system with higher density and basal area. Tea bushes occupy dominant proportion $(84.9 \%)$ of basal area cover 
$0-30 \mathrm{~cm}$
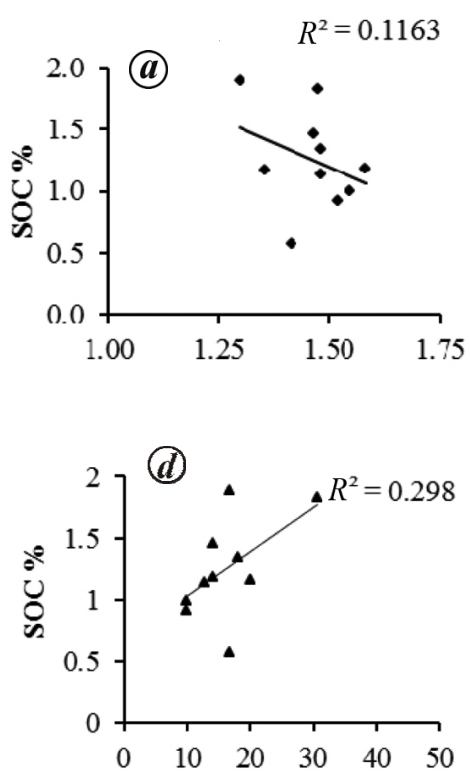

$30-50 \mathrm{~cm}$
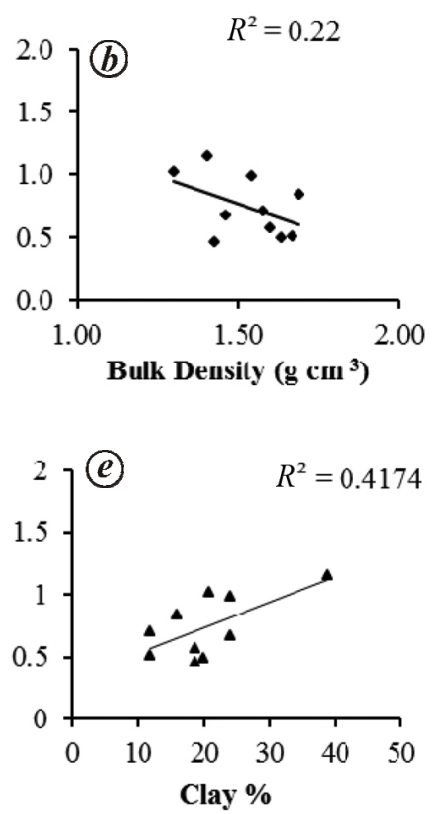

$50-100 \mathrm{~cm}$
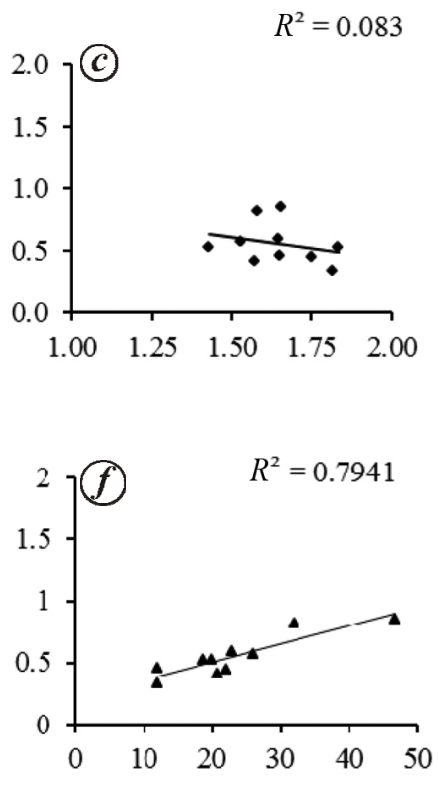

Figure 2. Relationship of soil organic carbon concentration (SOC\%) with bulk density $(\boldsymbol{a}-\boldsymbol{c})$ and clay proportion $(\boldsymbol{d}-\boldsymbol{f})$ in different soil depths.

Table 3. Descriptive statistics for some soil properties under smallholder tea plantations

\begin{tabular}{lccccccc}
\hline Soil parameters & Soil depth $(\mathrm{cm})$ & Mean & Minimum & Maximum & SD & SE & CV (\%) \\
\hline Sand (\%) & $0-30$ & 50.06 & 16 & 66 & 17.31 & 5.47 & 34.58 \\
& $30-50$ & 47.02 & 11.28 & 68 & 17.82 & 5.64 & 37.90 \\
& $50-100$ & 44.02 & 9.28 & 70 & 19.10 & 6.04 & 43.38 \\
Silt (\%) & $0-30$ & 33.66 & 16 & 67.28 & 14.40 & 4.55 & 42.79 \\
& $30-50$ & 32.49 & 16 & 70 & 14.87 & 4.70 & 45.76 \\
& $50-100$ & 32.69 & 14 & 70 & 14.87 & 4.70 & 45.50 \\
Clay (\%) & $0-30$ & 16.29 & 10 & 30.72 & 5.72 & 1.81 & 35.14 \\
& $30-50$ & 20.49 & 12 & 38.72 & 7.27 & 2.30 & 35.46 \\
Bulk density $\left(\mathrm{g} \mathrm{cm}^{-3}\right)$ & $50-100$ & 23.29 & 12 & 46.72 & 9.63 & 3.04 & 41.35 \\
& $0-30$ & 1.46 & 1.30 & 1.58 & 0.08 & 0.03 & 5.59 \\
& $30-50$ & 1.53 & 1.30 & 1.69 & 0.12 & 0.04 & 7.92 \\
SOC (\%) & $50-100$ & 1.65 & 1.43 & 1.83 & 0.12 & 0.04 & 7.36 \\
& $0-30$ & 1.25 & 0.58 & 1.89 & 0.38 & 0.12 & 30.37 \\
& $30-50$ & 0.74 & 0.46 & 1.16 & 0.23 & 0.07 & 31.47 \\
& $50-100$ & 0.55 & 0.33 & 0.85 & 0.16 & 0.05 & 28.81 \\
\hline
\end{tabular}

followed by shade tree $(15.1 \%)$ compartment across different plantations. Biomass carbon stock in smallholder tea plantations was estimated to be $30.50 \pm 3.15 \mathrm{Mg} \mathrm{ha}^{-1}$, depicting a range of 21.99 (SH-2) to $56.74 \mathrm{Mg} \mathrm{ha}^{-1}$ (SH-7). Shade trees and tea bush compartments allocated $17.19 \pm 2.95$ and $7.77 \pm 0.37 \mathrm{Mg} \mathrm{ha}^{-1}$ carbon in biomass. Carbon stock in litter compartment was assessed from 4.33 (SH-5) to $7.23 \mathrm{Mg} \mathrm{ha}^{-1}$ (SH-7), with a mean estimate of $5.54 \pm 0.30 \mathrm{Mg} \mathrm{ha}^{-1}$ (Figure 1). Leaf and non-leaf litter compartments shared proportionate contribution of $52.3 \%$ and $47.7 \%$ respectively, towards carbon stock. Above and belowground compartment contributed
$19.66 \pm 2.39$ and $5.30 \pm 0.62 \mathrm{Mg} \mathrm{ha}^{-1}$ towards carbon stock.

In different plantations-shade tree compartment contributed dominant proportion $(56.37 \%)$ of biomass carbon stock followed by tea bushes $(25.46 \%)$ and litter compartments (18.17\%) (Figure 1). Carbon stock in shade trees, tea and litter compartments across different plantations showed significant variation ( $t$-test, $P<0.01)$. Above- and below-ground compartments showed similar proportion of biomass and carbon allocation in different plantations, with mean proportionate contribution of $78.7 \%$ and $21.3 \%$ respectively. 


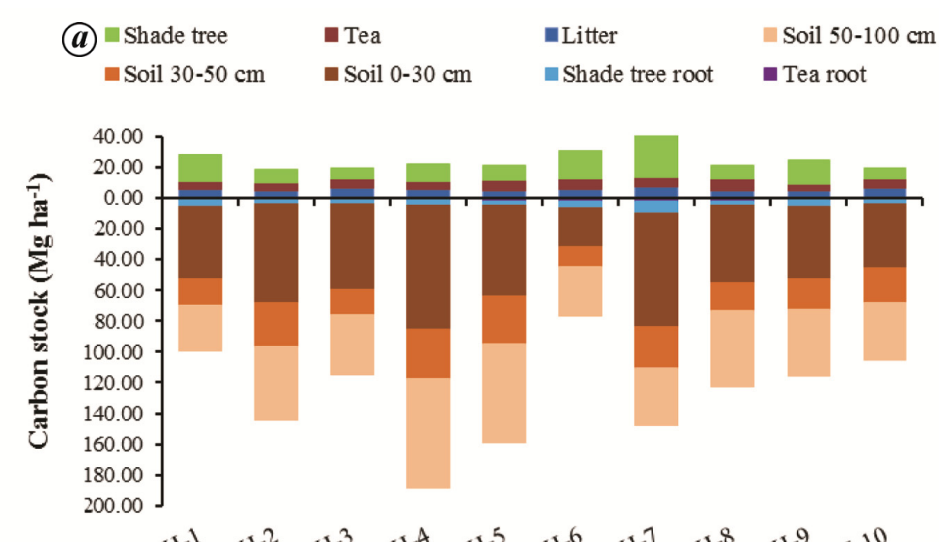

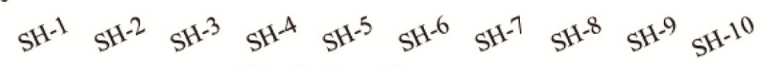

Plantation sites

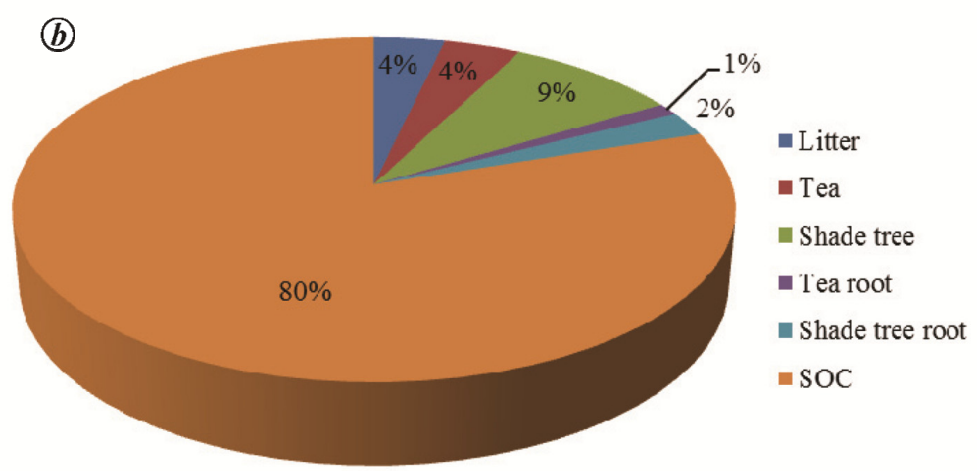

Figure 3. Distribution of carbon stock in different compartments $(\boldsymbol{a})$ and proportionate carbon stock in the compartments $(\boldsymbol{b})$ in smallholder tea plantations.
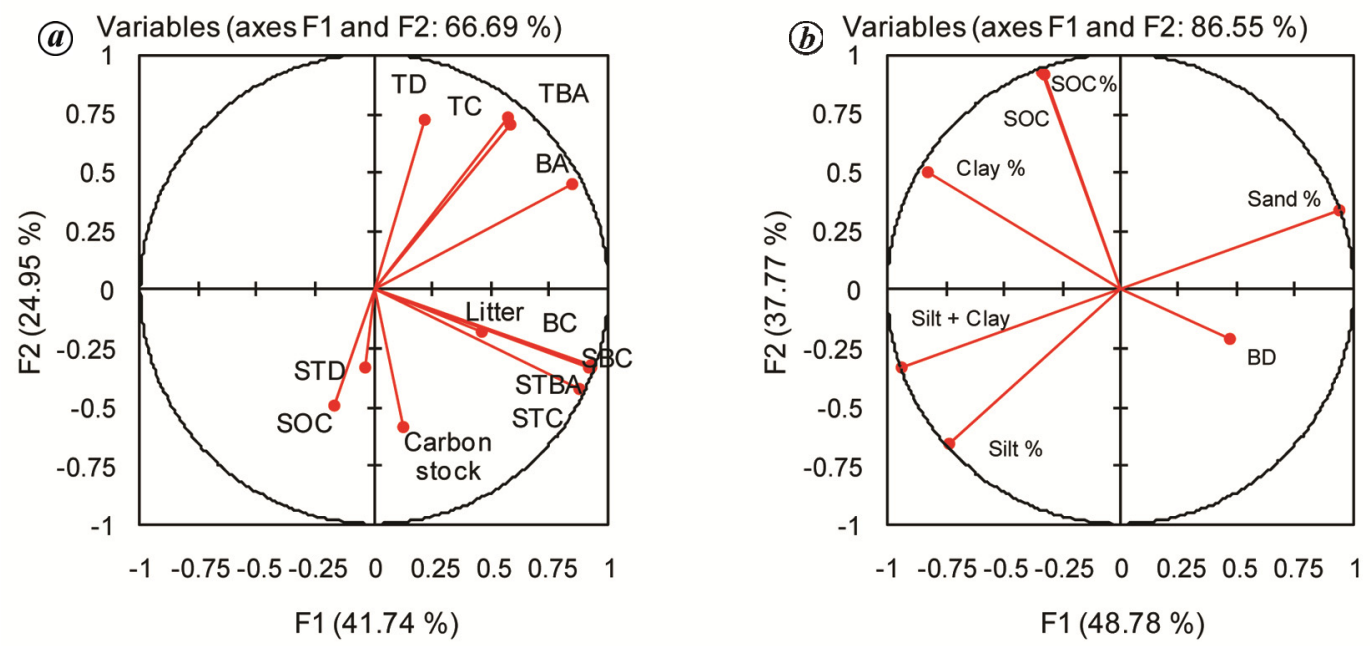

Figure 4. $\boldsymbol{a}$, Association of stand density, basal area, carbon stock in biomass and soil compartments. $\boldsymbol{b}$, Association of soil physico-chemical properties in smallholder tea plantations. BA, Stand basal area; BC, Biomass carbon; BD, Bulk density; SOC, Soil organic carbon (stock); SOC\%, soil organic carbon (concentration); STBA, Shade tree basal area; STD, Shade tree density; STTC, Shade tree total carbon; TBA, Tea basal area; TC, Tea carbon; TD, Tea density; TTC, Total tea carbon.

In the different sampled sites, soil exhibited dominance of yellowish-brown colour in the top $(0-30 \mathrm{~cm})$, middle $(30-50 \mathrm{~cm})$ and bottom $(50-100 \mathrm{~cm})$ depths. Sandy loam was the dominant textural class in all depths across sam- pling sites. BD values ranged from 1.30 to $1.83 \mathrm{Mg} \mathrm{m}^{-3}$, and gradually increased from top to bottom soil. The total soil organic carbon (TOC) varied between $0.33 \%$ and $1.89 \%$. Soil organic carbon concentration (SOC\%) 


\section{RESEARCH COMMUNICATIONS}

gradually decreased with increasing soil depth (Table 3). Across all sites BD presented negative relation with SOC\% (Figure $2 a-c$ ). Clay proportion in the soil presented significant correlation with SOC \% in different soil depths across plantation sites (Figure $2 d-f$ ). Mean SOC $\%$ was estimated to be $1.25 \%, 0.74 \%$ and $0.55 \%$ for top, middle and bottom soil layer respectively. SOC $\%$ in different plantation sites and soil depths showed variations with statistical significance (ANOVA, $P<0.05$ ). Mean SOC stock in this study evidenced $122.17 \pm$ 9.82 $\mathrm{Mg} \mathrm{Cha}^{-1}$ up to $1 \mathrm{~m}$ depth. The estimated values ranged from 70.09 to $183.55 \mathrm{Mg} \mathrm{C} \mathrm{ha}^{-1}$ across different smallholder plantations (Table 2).

Carbon stock in small holder tea plantations was estimated to be $152.67 \pm 9.98 \mathrm{Mg} \mathrm{ha}^{-1}$ and ranged from 107.69 to $210.63 \mathrm{Mg} \mathrm{ha}^{-1}$ across different stands. Soil compartment hold maximum proportion $(80 \%)$ of carbon stock followed by shade tree $(11 \%)$, tea bush $(5 \%)$ and litter (4\%) compartments in the system. Figure 3 shows the distribution of $\mathrm{C}$ stocks in the different compartments and proportionate contribution towards carbon stock. SOC stock in the smallholder plantations exhibited substantial variations among the sites (ANOVA; $P<0.05$ ) with probable impact of previous land-cover history of the plantations. SOC $\%$ and stock in all the respective depths were significantly lower in SH-6, where previous land cover (paddy land/fallow) was different from other sites (forest/degraded forest). This indicates the influence of land-cover history of the plantation on carbon stock potential of the system, particularly in the soil compartment. Retaining considerable amount of carbon in soil compartment in the plantations resulting from forest conversion highlights the utility of the smallholder tea plantations towards climate change mitigation and adaptation with reasonable compensation for forest conversion and livelihood security for smallholder tea growers.

Standing biomass carbon stock estimate (24.96 \pm $\left.3.02 \mathrm{Mg} \mathrm{ha}^{-1}\right)$ in the present study is lower than that $\left(53.05 \mathrm{Mg} \mathrm{ha}^{-1}\right)$ in larger tea plantations of similar ages in the region ${ }^{14}$. The estimate was also lower than those reported for tea plantations from China $\left(50.9 \mathrm{Mg} \mathrm{ha}^{-1}\right)^{12}$ and Kenya $\left(43-72 \mathrm{Mg} \mathrm{ha}^{-1}\right)^{13}$. Carbon stock in litter compartment in the study showed comparatively lower estimate than larger-scale plantations in the region, but higher value than estimated stock for tea plantations from China $\left(50.9 \mathrm{Mg} \mathrm{ha}^{-1}\right)^{12}$. SOC stock in smallholder tea plantations presented comparatively lower estimate $\left(122.17 \mathrm{Mg} \mathrm{ha}^{-1}\right)$ than larger tea plantations of similar ages $\left(125.45 \mathrm{Mg} \mathrm{ha}^{-1}\right)$ in the region ${ }^{14}$ and tea plantations from China (137.5 $\mathrm{Mg} \mathrm{ha}^{-1}$ up to $\left.60 \mathrm{~cm} \mathrm{depth}\right)^{12}$. Considering the paucity of data on carbon stock assessment in smallholder tea plantations, it is difficult to compare these findings with similar land-use systems. Basal area of shade tree and tea exhibited significant correlation with biomass carbon allocation in the compartment, with a correlation coefficient of $r=0.96$ and $r=0.99$ respectively.
Factor analysis revealed that carbon stock potential of the plantation sites is mainly driven by soil compartment following biomass compartment, highlighting the major influence of shade tree density, basal cover and stocks on total carbon stock estimates (Figure $4 a$ ). Apart from this, the type of shade tree influenced carbon stock in the compartment in the system. Analysis of soil parameters revealed that SOC presented reverse association with bulk density and sand proportion, whereas this parameter was positively influenced by clay particles (Figure $4 b$ ).

Smallholder tea plantations have considerable implications for climate change mitigation, holding a considerable reservoir of carbon in biomass and soil compartments. Assessment of carbon stocks in smallholder tea plantation systems may have wide implications in the context of bioenergy and carbon sequestration. Understanding the phytosociology and carbon dynamics in this potential system could provide decision support for proper shade management, pest management, rational use of fertilizers to improve the yield and quality of tea along with environmental services through climate change mitigation. Likewise, well-managed smallholder tea plantations might have implications to compensate for the loss of carbon stocks resulting from land-use conversion, and sustainable production of tea providing financial benefits to smallholder tea growers.

1. Le Quere, C. et al., Global carbon budget 2015. Earth Syst. Sci. Data, 2015, 7, 349-396.

2. Dlugokencky, E. and Tans, P., Trends in atmospheric carbon dioxide. National Oceanic and Atmospheric Administration, Earth System Research Laboratory (NOAA/ESRL), USA; http:/www. esrl.noaa.gov/gmd/ccgg/trends (last accessed on 26 July 2016).

3. Houghton, R. A., Balancing the global carbon budget. Annu. Rev. Earth Planet. Sci., 2007, 35, 313-347.

4. Kumar, B. M. and Nair, P. K. R. (eds), Carbon Sequestration Potential of Agroforestry Systems, Springer, The Netherlands, 2011.

5. Tea Board of India, Tea statistics. Ministry of Commerce \& Industry, Government of India, 2014; http://teaboard.gov.in (accessed on 17 January 2015).

6. Das, T. and Das, A. K., Mapping and identification of homegardens as a component of the trees outside forests using remote sensing and geographic information system. J. Indian Soc. Remote Sensing, 2013, 42, 233-242.

7. Committee on Commodity Problems, Contribution of smallholders to the tea sub-sector and policies required to enhance their livelihood. In Intergovernmental Group on Tea (CCP: TE 12/4, pp. 1-6). 20th Session, Colombo, Sri Lanka, 30 January-1 February 2012.

8. Onduru, D. D., De Jager, A., Hiller, S. and Van den Bosch, R., Sustainability of smallholder tea production in developing countries: learning experiences from farmer field schools in Kenya. Int. J. Dev. Sustain., 2012, 1, 714-742.

9. Dawson, I. K. et al., Trees, tree genetic resources and the livelihoods of rural communities in the tropics. In Thematic Study for the State of the World's Forest Genetic Resources. Food and Agriculture Organization of the United Nations, Rome, Italy, 2013.

10. Koul, D. N. and Panwar, P., Prioritizing land management options for carbon sequestration potential. Curr. Sci., 2008, 95, 658663. 
11. Wijeratne, T. L., De Costa, W. A. J. M. and Wijeratne, M. A., Carbon sequestration potential of tea plantations in Sri Lanka. In Conference paper 228th Experiment and Extension Forum, Colombo, Sri Lanka, 2014.

12. Li, S. et al., Quantifying carbon storage for tea plantations in China Agric. Ecosyst. Environ., 2011, 141, 390-398.

13. Kamau, D. M., Spiertz, J. H. J. and Oenema, O., Carbon and nutrient stocks of tea plantations differing in age, genotype and plant population density. Plant Soil, 2008, 307, 29-39.

14. Kalita, R. M., Carbon storage and sequestration in tea agroforestry system in Barak Valley, Assam. Ph D thesis, Assam University, Silchar, 2015.

15. Singh, S. and Dadhwal, V. K., Vegetation Carbon Pool Assessment of India, Indian Institute of Remote Sensing, Dehradun, 2009.

16. Mayer, H. D. G., A manual and tutorial for the proper use of an increment borer. Tree Ring Res., 2003, 59, 63-79.

17. FRI, Indian Woods, Volume I-VI, Forest Research Institute, Dehradun, 1996.

18. Zanne, A. E. et al., Global Wood Density Database, Dryad, 2009; http://hdl.handle.net/10255/dryad.235.

19. FSI, Volume Equations for Forests of India, Nepal and Bhutan, Forest Survey of India, Dehradun, 1996.

20. Devagiri, G. M. et al., Assessment of above ground biomass and carbon pool in different vegetation types of south western part of Karnataka, India using spectral modeling. Trop. Ecol., 2013, 54, 149-165.

21. Ravindranath, N. H. and Ostwald, M., Carbon Inventory Methods Handbook for Greenhouse Gas Inventory, Carbon Mitigation and Roundwood Production Projects, Springer, The Netherlands, 2008.

22. IPCC, Intergovernmental Panel on Climate Change 2007. Synthesis Report, 2007; http://www.ipcc.ch/pdf/assessment-report/ar4/ syr/ar4 syr.pdf (accessed on 10 May 2011).

23. Kalita, R. M., Das, A. K. and Nath, A. J., Allometric equations for estimating above and belowground biomass in tea (Camellia sinensis (L.) O. Kuntze) agroforestry system of Barak Valley, Assam, Northeast India. Biomass Bioenerg., 2015, 83, 42-49.

24. Newbould, P. J., Methods for Estimating the Primary Production of Forests, IBP Handbook No. 2. Blackwell Scientific Publications, Oxford, 1967, p. 62.

25. Velmurugan, A., Kumar, S., Kudrat, M. and Dadhwal, V. K., Spatial Assessment of Soil Carbon Pool of India, Indian Institute of Remote Sensing, Dehradun, 2009.

26. Bouyoucos, G. H., Hydrometer method improved for making particle size analyses of soils. Agron. J., 1962, 54, 464-465.

27. Brady, N. C. and Weil, R. R., The Nature and Properties of Soils, Pearson Education, New Jersey, 2008, 14th edn.

28. Chan, K. Y., Bowman, A. and Oates, A., Oxidizable organic carbon fractions and soil quality changes in an oxicpaleustalf under different pasture leys. Soil Sci., 2001, 166, 61-67.

ACKNOWLEDGEMENTS. We thank the Council of Scientific and Industrial Research, New Delhi for financial support (Scheme number: 38(1349)/13/EMR-II dt.14.02.2013) to undertake this study. We also thank the Tea Research Association Cachar Advisory Centre for providing meteorology data, and smallholder tea growers for permission to carry out research in their plantations.

Received 3 August 2016; accepted 29 November 2017

doi: $10.18520 / \mathrm{cs} / \mathrm{v} 116 / \mathrm{i} 9 / 1560-1566$

\section{Phylogenomic analysis and gene organization of mitogenome from Mong Cai pig in Vietnam}

\author{
Thuy Thi Bich Vo ${ }^{1, *}$, Hieu Duc Nguyen ${ }^{1}$, \\ Tuan Anh Bui ${ }^{2}$, Binh Thi Nguyen Le ${ }^{1}$, \\ Minh Ngoc Nghiem ${ }^{1}$ and Hai Van Nong ${ }^{1}$
}

${ }^{1}$ Institute of Genome Research, Vietnam Academy of Science and Technology, Hanoi 1000000, Vietnam

${ }^{2}$ Institute of Forensic Science, 99, Nguyen Tuan, Thanh Xuan, Hanoi 100000, Vietnam

Mong Cai pig (Sus scrofa) is the Vietnamese indigenous pig breed. The complete mitogenome of this breed has been sequenced and characterized. It is deposited in GenBank with accession number KX147100. There were 37 genes (13 protein-coding, 2 rRNA, 22 tRNA genes and a control (D loop) region) located in 16,711 bp of complete mitogenome. The phylogenetic relationships of both mitogenome and $D$ loop region revealed the shortest genetic distance with Lantang pig breeds and close relationship to some other pig breeds in China regions. Taken together, the valuable data provide essential information for genetic and phylogenetic studies in Vietnamese indigenous animal.

Keywords: Genetic distance, mitochondrial-genome, Mong Cai pig, phylogenetic relationships.

VIETNAM has twenty native breeds of pigs and most of them have been recognized as must conserve livestock gene sources of Vietnam ${ }^{1}$. The Mong Cai pigs are one among them and largely distributed in the provinces of the Northern region, and the northern part of the Central Coastline in Vietnam. They are known for high fertility, withstand low-nutrient food, hot climate condition and resistance to infectious diseases. In the 70's years of the last century, the Mong Cai pig breeds were popular in the northern area, but their population size has reduced now because of the replacement with high growth foreign pig breeds. Thus there is risk of disappearance of Mong Cai pig breed in the livestock map. The excellent indigenous genetic resources should be conserved and protected to effectively use these animal gene resources and contribute to the restoration plan.

Owing to the advantages of molecular methods, one of these methods, mitochondrial (mt) DNA polymorphism has become a useful tool to determine and understand many aspects of animal origin and the dispersal of animal species in the world ${ }^{2,3}$. In addition, the variability of the control region is considered to be important as it may show the phylogenetic events in the past and is used to analyse genetic distances among breeds ${ }^{4}$. Thus the alterations in the non-coding control region sequence used for

*For correspondence. (e-mail: thuytbvo@igr.ac.vn) 